Clenio Perlin Berni

\title{
Tecnologias e tempo docente
}

Universidade Federal de Santa Maria (UFSM), Santa Maria/RS - Brasil

Fábio da Purificação de Bastos

Universidade Federal de Santa Maria (UFSM), Santa Maria/RS - Brasil

KENSKI, Vani Moreira. Tecnologias e tempo docente. São Paulo: Papirus, 2013.

A obra de Vani Moreira Kenski expõe o resultado da pesquisa sobre as tecnologias aplicáveis à educação, no exercício da docência. Em seu dia a dia, o professor segue em uma busca incessante por metodologias associadas às tecnologias educacionais, que podem vir a ser implementadas nos novos currículos de formação acadêmica profissional, nas esferas institucionais de nosso país. O objetivo é chega a um ensino-aprendizagem que seja condizente com a nova realidade que se apresenta.

A primeira parte da obra, denominada "o tempo buscado, relativizado e redefinido," congrega os cinco primeiros capítulos, em que a autora faz reflexões sobre: os tempos e os movimentos; as tecnologias, a vida contemporânea e a organização temporal; a organização temporal na educação escolar; os tempos tecnológicos e uma nova cultura de ensino e aprendizagem; e usos das novas tecnologias no ensino superior.

$\mathrm{Na}$ segunda parte, "temporalidades na formação do docente", trata, de forma mais específica, da questão do tempo no contexto educacional. Esse enfoque do capítulo 6 evidencia novos tempos de formação docente, passando pelos desafios da educação a distância na formação de docentes, para temporalidades docentes nos ambientes virtuais, e eras digitais e ações abertas de ensino e formação, para que o professor possa atuar com o máximo de qualidade, em qualquer espaço e tempo.

Os novos meios de interação professor-aluno que as tecnologias proporcionam não garantem ensino de qualidade sem compartilhamento de ações voltadas para as novas modalidades de ensinar/aprender de forma colaborativa. Já na formação docente, deve-se mostrar os caminhos e possibilidades das tecnologias para a organização da função e a partilha da atuação em equipe. 
O novo profissional da educação passa por uma transformação em cadeia, desde o modo como é preparado na licenciatura até a prática em sala de aula. Todo esse percurso mudou muito com as tecnologias, alterando o modo de agir do docente na atualidade. Para a autora, o tempo do conhecimento tecnológico é múltiplo e atual. Como agir para compreender e ensinar conteúdos em movimento constante, como preparar as referidas aulas, presenciais ou on-line docentes e como articular-se para as atividades on-line.

As possibilidades tecnológicas atuais devem ser vistas pelos profissionais como ferramentas a serem exploradas, no intuito de trazer para o debate toda a sociedade envolvida com o ensino, de forma a agregar e multiplicar o interesse pelos temas a serem debatidos, passando por uma reforma nos currículos escolares e da academia. Na vida profissional de um educador, novos tempos e temporalidades já se fazem presentes, no tempo buscado, relativizado e redefinido, seja nas urgências de demandas ou na pressa do aprendizado das tecnologias na vida contemporânea. Cabe ressaltar o tempo dedicado à ação docente, remunerado e não remunerado das presenciais e não presenciais, numa constante e permanente interatividade, estando ou não em seu período de trabalho.

Kenski articula, em sua narrativa, relatos de experiências de formação e processos de teorização de seu trabalho como educadora, conduzindo o leitor a acompanhar o movimento crescente do uso das tecnologias nas práticas docentes e as novas possibilidades de teorização/prática, delas decorrentes, em um processo analítico permanente. Tempos múltiplos, apressados, urgentes, difíceis, mostrando que estamos sempre em uma corrida incessante em busca do tempo perdido, sobretudo para acompanhar as inovações tecnológicas.

Nesse sentido, analisa o papel das tecnologias digitais e da educação aberta, assim como a distância, como meios importantes para otimização do tempo e do movimento. A obra resenhada busca verificar as relações entre educação, comunicação e tecnologias inovadoras. Tempo e espaço são dimensões fundamentais em qualquer planejamento e não menos importantes no planejamento de toda atividade escolar. Aonde e quando vão se desenvolver as ações pedagógicas são variáveis básicas, necessárias para definir as estratégias e os recursos e delimitar o conteúdo a ser trabalhado, 
entre tantas outras ações pertinentes ao planejamento pedagógico, em todos os níveis e modalidades.

Com o uso cada vez mais intenso das tecnologias de comunicação nos cursos presenciais e, especialmente, nos cursos ofertados na modalidade a distância, a distribuição do tempo pedagógico sofre grandes mudanças, demandando estudos e pesquisas que busquem adequar carga horária e tempo necessários para desempenhar as tarefas inerentes à rotina dos professores que se dedicam à docência on-line.

Ao iniciar suas reflexões na apresentação, a autora defende a ideia de que as ações compartilhadas são um caminho possível para resolver as questões das dificuldades que os professores encontram para desempenhar suas atividades (algumas constatações se evidenciaram no decorrer do estudo). Uma delas é que o tempo dedicado por eles ao exercício de sua profissão, em sua nova versão, com o emprego frequente dos meios virtuais de interação e comunicação, é um dos aspectos mais evidentes da dificuldade de incorporação de múltiplas funções em um único docente.

O trabalho é enorme para o planejamento, a produção e o oferecimento das atividades educacionais mediadas. O tempo é escasso e, sem compartilhamento, a atuação em equipe e a colaboração, torna-se impossível o desenvolvimento de ações de qualidade. Ocorre que esse tempo geralmente não é mensurado, não há previsão de um período determinado na carga horária do professor para fazer esse tipo de atendimento. Como equalizar as rotinas, os processos, o número de alunos por turma, o grau de interatividade que o professor precisa para atendê-los, com a jornada oficial de trabalho? É preciso que os professores se apropriem das novas tecnologias, mas é preciso, paralelamente, que as políticas públicas de governos contemplem as novas competências que professores, alunos e instituições de ensino precisam, ainda, incorporar.

Esta é uma época de novas temporalidades e novos espaços. No espaço virtual, as relações que se estabelecem são outras, pois o professor não entra em uma sala de aula, fecha sua porta e se relaciona com seus alunos na intimidade do grupo. Não há intimidade no ambiente virtual, tudo é exposto e, portanto, passível de ser observado e interpretado sem uma contextualização adequada da relação que o professor estabelece com a 
turma. Até porque, cada vez mais, são ampliadas as possibilidades de comunicação por meio de variados recursos de interação, disponíveis em smartphones, tablets, entre outros.

Essas são peculiaridades que demonstram a necessidade de mudanças estruturais nos currículos, na administração, na organização do trabalho e na hierarquia de poderes que permeiam as esferas educacionais. Diante desse contexto, a autora levanta algumas das principais questões que são abordadas no livro: na atualidade, com múltiplas formas de interação e de articulação entre professores e alunos por via dos ambientes virtuais, listas, e-mails, chats e outras maneiras síncronas e assíncronas de comunicação, como calcular o tempo docente?; Como calcular o tempo das disciplinas?; Como calcular o tempo necessário para aprender?

Ao longo de sua obra, a escritora destaca a distinção entre ações de formação, provocadas pelas tecnologias de informação e comunicação inovadoras; tempos de formação; os novos desafios com a educação a distância; temporalidades na era digital; e ações de ensino e formação. Sendo que, para tudo isso, é preciso planejamento para produção e oferecimento ao público. Por meio das redes tecnológicas, professor e aluno podem refletir, discutir e interagir uns com os outros, na teoria e na prática e, assim, criar novas formas de procedimentos que venham a auxiliar na prática profissional. Para melhor exemplificar a missão educação, a autora apresenta quatro pilares do conhecimento: aprender a conhecer; aprender a fazer; aprender a viver juntos; e aprender a ser, o que, para nós, é aprender a trabalhar de forma colaborativa.

Assim, considera-se Tecnologias e tempo docente como uma obra de referência para o campo da formação continuada docente. Vive-se de mudanças constantes, é preciso fluência tecnológico-pedagógica cada vez maior para se interagir com o novo. Em muitos setores, como a educação, essa capacidade não foi ainda desenvolvida no ritmo adequado, não incorporando as novidades aos seus processos. O livro provoca reflexões sobre essa necessidade de adaptação a novos tempos para aprender e educar, de forma colaborativa, associada às tecnologias. 